doi: $10.19090 / \mathrm{i} .2015 .26 .18-36$

UDC: $811.14 ’ 373.23$

ORIGINAL SCIENTIFIC PAPER

Received: 29 April 2015

Accepted: 1 August 2015

\title{
MIRKO OBRADOVIĆ
}

University of Belgrade, Faculty of Philosophy

mdobrado@f.bg.ac.rs

\section{CONTRIBUTIONS TO THE STUDY OF NELEID ANTHROPONYMY IV: THE HEROIC NAME NESTOR AS A PERSONAL NAME AMONG THE HELLENES}

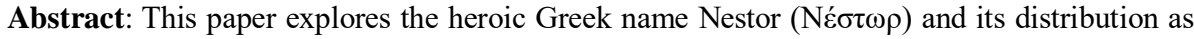
a personal name in the Hellenic world. The name Nestor, as a personal name, is almost equally common in the Ionian areas of the Hellenic World (Attica, the islands in the Cyclades, Ionia in Asia Minor), as it is in the predominantly Doric areas (Peloponnese, the islands of Rhodes and Kos), but also in Epirus, Macedonia and in the Hellenic settlements beyond the mainland Greece. It is indisputable that this distribution of the name must have been influenced by the fact that Nestor was one of the most notable heroes of ancient Hellenic epics with a significant role in the two most important Homeric epics. As in the case of some other Neleid names, the heroic name Nestor could have seemed attractive and desirable for naming male children, in particular from the point of view of Nestor's glorious offspring with whom several aristocratic families from different parts of the Greek world wanted to be identified. Additionally, in the subsequent periods (Hellenistic and Roman), the names taken from the mythological repertoire were very popular among the educated members of the local elites. They perceived Nestor as a model of a wise teacher and counselor. It seems that the name Nestor might have sound to contemporaries primarily as a good name for a wise and educated Hellene. In this way, the reasons for giving the name Nestor to newborn Hellenic children gradually moved from the sphere of politics to the sphere of culture, as had been the case with some other heroic names, but also with some which were not associated with heroes.The anthroponym Nestor at the time often occurred in combination with other heroic names.

Keywords: Nestor, Greek anthroponymy, Neleid, etymology, the Greek epic, myth, history, politics, cultural values.
\end{abstract}

$\mathrm{W}$

e are going to continue our research of Neleid heroic names which appear as personal names among ancient Greeks by analyzing the name Nestor

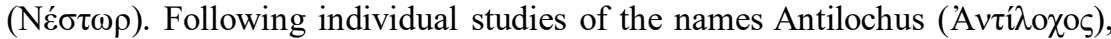

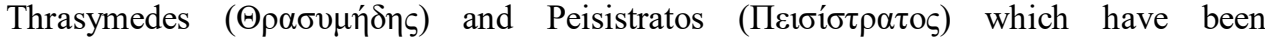
successively published over the previous couple of year in this same journal, ${ }^{1}$ this is truly

${ }^{1}$ Cf. Obradović 2012: 95-109; Obradović 2013: 23-39; Obradović 2014: 25-42. 
an expected continuation of our studies in this field and of our undertaking of seeking out possible reasons for naming mortal men after characters from the heroic repertoire. It may well be that the entire investigation of the Greek anthroponymy based on heroic Neleidae should have begun with the name of the hero Nestor. One could find more than a few good reasons for this. The main reason is surely that it was the name of one of the greatest heroes of the Greek epics: Nestor, the son of Neleus, the old and wise king of the legendary Pylos in the Peloponnese. In the Hellenic tradition, Nestor is a hero who symbolizes wisdom, experience, and a happy and hearty old age, more than any other hero. He has an important role in both greatest Homeric epics (the Iliad and the Odyssey), and the poet of the Iliad had already known him very well for the heroic deeds he had committed both as a youth and as an adult. ${ }^{2}$ This is almost a unique case when it comes to heroes in the Homeric epics, which could be interpreted as an indication of the hero's long presence in the pre-Homeric epic traditions. On the other hand, this same Nestor had been mentioned, both by Homer and by subsequent ancient poets and storytellers, as a participant of virtually all well-known heroic enterprises and sagas of the Hellenic tradition: the Trojan War, the Centauromachy, the Calydonian Hunt, even in the story of the Argonauts and other similar heroic epics. ${ }^{3}$

Therefore, the very name Nestor may have become attractive and desirable for naming children in different periods of the Hellenic history, in particular from the point of view of Nestor's glorious offspring (the Neleidae) with whom several aristocratic families from different parts of the Greek world wanted to be identified. This holds particularly true for the Greek Ionian areas with strong Neleid traditions, but later in this paper it will be proven that this was not a practice which was exclusive to the Ionian tribe. Similarly, in the subsequent periods (Hellenistic and Roman) this name was appropriate for naming children among the educated members of the local elites in Greek poleis, who perceived Nestor as a model of a wise teacher and counselor.

The next, no less important, reason why it is exactly Nestor who should be the starting point for analyzing heroic Neleid names given to mortal men, could be the fact that it has been confirmed that it is exactly his name which is the oldest heroic name which appears in a Greek inscription made in the Greek alphabet. The inscription is the one carved on a cup (a skyphos, a characteristic two-handled deep wine-cup measuring 10x15 cm) made somewhere in the eastern Aegean region, most probably on the island of Rhodes (the decoration best fits the late Geometric pottery of the Rhodean type), and which was found in 1954 in a grave on the island of Ischia (Pithecusae in the Hellenic period) in the Gulf of Naples. The inscription was carved from right to left and has the word-boundary sign which is characteristic of the Euboean form of the early Western Greek alphabet. The inscription, as well as the cup itself, is usually dated to the second half of the 8th century B.C. (some time between 735 and 720 B.C.) The famous first line of the inscription reads (in prose?): "I am Nestor's cup, good to drink from," which is

${ }^{2}$ Cf. eg. Il. XI 670-761, where Nestor tells Patroclus about the glorious battles which he had fought in his youth.

${ }^{3}$ Cf. J. Schmidt, RE 17, 1936, 108-123, s.v. Nestor(1); on Nestor's return from the Trojan War, cf. T. Gantz 1993: 662-663; for an analysis of Nestor's contingent and territories of his kingdom in cf. Visser 1997: 508-531; also E. Visser, $D N P$ 8, 2000, 861-863, s.v. Nestor (1). For less frequent iconographic depiction of hero Nestor in ancient times, cf. E. Lygouri-Tolia, LIMC VII, 1994, 1060-1065, s.v. Nestor. 
followed by two more lines written in a hexameter verse and which inform that whoever drinks from the cup will straightaway be seized by the desire of beautiful-crowned Aphrodite (i.e. that he will become obsessed with sexual desire and passion). ${ }^{4}$ Strictly speaking, the formula consisting from a personal name in the Genitive case + EIMI + the name of the object, which is extremely common in inscriptions made on various objects, represents a mark of ownership and gives ground to speculate that Nestor was in the first place the name of the owner of this cup and that the cup was used during symposiums. If this is the case, Nestor's Cup would represent the oldest recorded instance of using a heroic name to name mortal men in the Hellenic world as a whole. The grave in which the cup was found belonged to a young man, perhaps even a boy, which gave ground to speculate that the real owner of the cup (Nestor from the inscription) may have been his father or even his lover. ${ }^{5}$

However, having in mind that the term "Nestor's Cup" is both well-known and mentioned as early as in the eleventh book of the Iliad, ${ }^{6}$ it is quite reasonable and probable to assume that in the case of the inscription found on the island of Pithecusae, the text actually represented an allusion to the well-known verses from Homer's epic. By comparison, Nestor's Cup, as described by the poet of the Iliad, differs considerably from Nestor's cup found in the grave on the island of Pithecusae. Homeric Nestor's cup stood out for its size and golden ornaments and very few people, except the hero Nestor himself, were able to even lift it from the table if it had been filled-up. ${ }^{7}$ On the other hand, the cup found among the burial artifacts in the tomb on the island of Pithecusae is no match for Nestor's cup described by Homer, either in terms of its dimensions or in terms of its decorations. Yet, is it possible to assume, as some scientists have proposed, that the inscription is actually a humorous one, whereby the author, fully aware of the dimensions of "real" Nestor's Cup, wanted to make fun of the dimensions of his own cup? ${ }^{8}$ If this indeed is what Nestor's Cup from the island of Pithecusae is about, does it also imply that, regardless of the intentions and reasons behind the inscription, the author of the inscription knew about the Iliad or does it imply that Nestor's Cup was simply a term which had already been well known in pre-Homeric epics and it was from those epics that the author

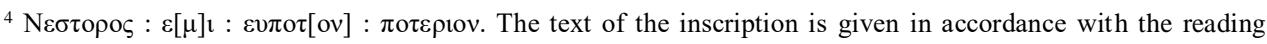
provided by Pavese 1996: 3 + Tafel II, Fig. 1-3, and after editio princeps from 1955 (cf. SEG 14, 604), the inscription has been published and copied in various publications and collections: Jeffery, LSAG, 235-236, 409 + Pl. 47; Meiggs-Lewis, GHI 1; Powell 1991: 163-164. Among more recent publications of the inscription's text, cf. also Arena, Iscrizioni III 2; Dubois, IGDGG I 2.

${ }^{5}$ Pavese 1996: 18-19.

${ }^{6}$ Il. XI 632-637. The poet of the Iliad, if truth be told, does not use the term $\pi$ otńptov which was found in the inscription, but uses $\delta \varepsilon \dot{\pi} \alpha \varsigma$ to refer to vessel which has four handles. A vessel with four handles is denoted exactly by the term di-pa also in tables from the Mycenaen era, which was proven a long time ago by Ventris, Chadwick 19732: 326-327. Cf. Hainsworth 1993: 292-293.

${ }^{7}$ Cf. Hainsworth 1993: 293; ad Il. XI 632-637.

${ }^{8}$ Cf. Hansen 1976: 40-43. A similar sentiment is shared already by Rüter, Matthiessen 1968: 246, as well as by Watkins 1976: 37-40. On the other hand, the magical elements in the the text of the inscription are analyzed by West 1994: 9-15, while Faraone 1996 especially from pg. 80 onward, in addition to spells he finds elements of curses in this text and in a whole series of other texts found in epigraphic monuments, which could give ground for this inscription to even be classified into the group of early defixiones. 
of the Iliad had taken it?

This is no easy issue to interpret, which can be seen from the fact that taking for granted that the author of the inscription and the owner of the cup from the island of Pithecusae, as well as people from his social circle, knew the Iliad and were so intimately familiar with Homer's verses that they were able to make allusions to them, necessarily implies a series of far-reaching conclusions and again opens up some questions about which there has been a long and great scientific controversy. These are, primarily, the questions pertaining to the time when Homeric epics were created and when they got the form in which they are now known. If the Euboean settlers on the island of Pithecusae ${ }^{9}$ were really familiar with Homeric epics, the definitive terminus ante quem for the creation of the Iliad would be around the year $730 \mathrm{BC}$, or even a couple of decades before that. ${ }^{10}$ Because if Nestor's Cup from the XI book of the Iliad is the cup to which the inscription alludes, the Iliad itself, as an epic, must have existed in the preceding decades. This conclusion reopens the issue of a possible link between the invention of the Greek alphabet and the final form of the epics, i.e. the need for for them to be recorded in writing. ${ }^{11}$

On the other hand, if one assumes that the inscription on the cup found on the island of Pithcusae cannot be considered a definite proof that Hellenic settlers in southern Italy knew Homeric epics in the second half of the 8th century BC, i.e. if the inscription is not an allusion to Homeric verses, the only logical conclusion would be that the inscription itself has nothing to do with the legendary cup described in the Iliad. In this case, the Nestor mentioned in the inscription could indeed be simply the owner of the cup. ${ }^{12}$ Many scientists who have analyzed the inscription in details often reject the claim that this is an instance of an anthroponym, partially because of a possible unfamiliarity with Greek anthroponymy, but partially because of a widespread prejudice and generalization that

\footnotetext{
${ }^{9}$ Strabo and Titus Livius, the only surviving literary sources which provide information about an early Greek settlement on the island of Pithecusae, wrote their works later, in the period of Octavius Augustus, but it is certain that they record earlier traditions: Strabo $(\mathrm{V} \mathrm{4,9)}$ states that the island of Pithecusae had once been inhabited by the Erythraeans and the Chalkidikians from Euboea who had been forced to flee their island because of unrests and earthquakes, while Titus Livius (VIII 22, 5-6) states that the Hellenic settlers in Kimah (in Italy) had arrived there from Euboea via Pithecusae and Aenaria (Aenaria, also an island in the Gulf of Naples.

${ }^{10}$ As claimed to be certain by Powell 1991: 219-220, who mentiones the aforementioned inscription as one of the most important arguments in favor of dating Homer and Homeric epics to the period between 800 and 750 године ВC. Nowadays, however, the standard reference for dating Homeric epics is Janko 1982, and the degree to which this whole issues is "alive" is exemplified by rather conflicting opinions of contemporary researchers which have been collected in Andersen, Haug 2012.

11 The idea that the original Greek alphabet was created exactly for the purpose of recording the Greek hexameters was put forward in the middle of the previous century by Wade-Gery 1952: 11-14, that is, in the years before the discovery of "Nestor's Cup" on Pithecusae. This hypothesis was revived, with some modifications, by Barry Powell, who also provided additional examples of poetic hexameters having been carved in stone or written on ceramic objects. Cf. Powell 1991: 109-10, pg. 148 and onward.

12 Cf. Pavese 1996: 4-7, who uses a whole series of similar examples (6 more earlier occurrences found only on the island of Pithecusae) to prove that this was an instance of a common inscription which indicated ownership and identified Nestor as the owner of the object who, just like the object itself, had no connection with the legendary Nestor.
} 
names of heroes and characters from Greek epics were rarely given to mortal men during the early periods of the Hellenic history. ${ }^{13}$ Such generalizations, however, do not hold true and must be abandoned. On the other hand, it seems perfectly logical and attractive to assume a connection between the text of the inscription on the cup from the island of Pithecusae and Homeric epics, and this fact cannot be easily dismissed. How is one then to reconcile these two apparent extremes and the conclusions about the meaning and origin of the inscriptions, when they seem to be completely contradictory? The solution, it seems, could be "within reach" if one assumes that this was a coincidence where the owner of the cup from the island of Pithecusae, just like the great hero celebrated in the cup named after him, happened to bear the same name: Nestor. This historical Nestor, aware of the existence and dimensions of the "famous" cup from the epic, made an allusion to the Homeric verses and joked, in a subtle and stylish way, about his own cup, which had clearly been used during symposiums. It is exactly in the context of symposiums that the text of the inscription becomes interesting to the maximum and reaches its full meaning. ${ }^{14}$

Even if one is to adopt the view that this was an instance of a Hellene bearing the name Nestor (an Euboean settler) on the island of Pithecusae in the second half of the 8th century $\mathrm{BC}$, this is a completely different question from whether he could have been given that very name in any other way except as a reference to the great hero Nestor, the legendary King of Pylos. This question is even more interesting because it was exactly the name Nestor, i.e. one of its variants, which can be claimed to have been confirmed as early as in the epoch of the Mycenaean Linear B. printed tables. Etymologically, the heroic

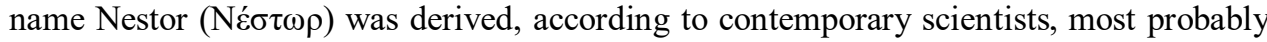
from the verb vह́oual (to come, to happily return) and is apparently related to the word

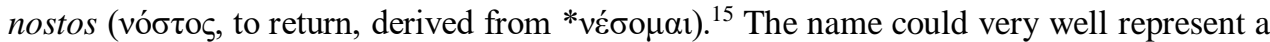
hypocoristic of the personal name Nestijanor which was recorded on several tables found in Pylos, but also in Thebes, in the form of Ne-ti-ja-no /Nes-ti-anor/, but also in the Dative case form of Ne-ti-ja-no-re /Nesti-anorei/. ${ }^{16}$ The name Nestijanor, with its most probable meaning of "the one who brings people back home", seems to be a perfect fit for the "lucky" Nestor who is one of few Achaean warriors that have made, together with their warriors, relatively uneventful happy returns to their homes after the Trojan War. The name is, therefore, most likely a "characterizing" name (Sprechender Name), while its formation follows the common and to-be-expected pattern of forming personal names by

\footnotetext{
13 This claim, which can often be found in older reference titles, but also occasionally in more recent titles, is very well formulated by e.g. Powell 1991: 165 note. 118: "Epic names of historical persons are extremely unusual in Greece until Hellenistic times, convincing many that the cup's owner could not have been named Nestor". Cf. Pavese 1996: 12-13, for a justified criticism of these claims.

${ }^{14}$ Cf. Murray 1994: 47-54.

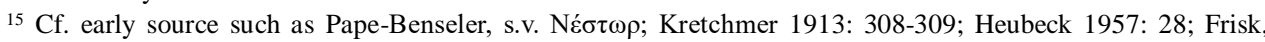

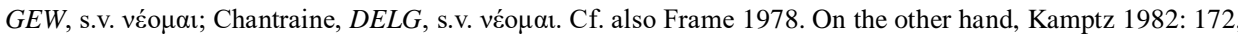
252-253, allows for the possibility that, in addition to the root *nes- (véo $\mu \alpha 1)$, a name may have have been derived from the root *ned- with the original meaning of "flow, ripple", which was, for example, confirmed in

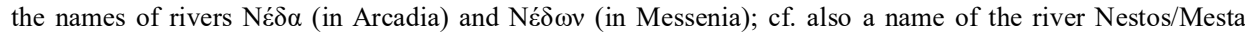

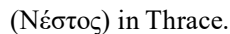

${ }^{16}$ PY Cn 40; PY Cn 599; TH Av 106. Cf. early source such as Ventris, Chadwick 1973²: 563 index.
} 
derivation from -anor, -andros, which is also the pattern which appear in heroic names,

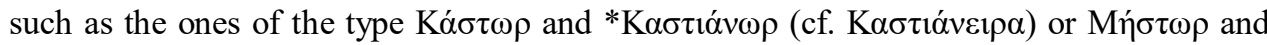

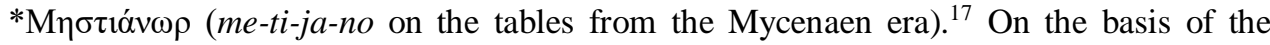
aforementioned examples which confirm the relatedness of the compound personal name (Nestijanor) as a personal name in the Mycenaen anthroponymy, is it possible that the "historical" Nestor from the island of Pithecusae was just an instance of a name which had somehow "survived" from the Mycenaean era, which was a natural result of the Bronze Age heritage, or is it possible, on the other hand, to use it as a basis for looking for a specific historical background for the existence of this name? Is it possible, given the importance of Nestor and generally of the Neleidae in the traditions of the Ionians, that the name may have appeared among the first Euboean settlers in southern Italy on the island of Pithecusae in the Gulf of Naples as a part of the sense of the Ionian identity which had already been developed in the 7th century BC? We are, of course, not able to give reliable answers to these questions. At this point it is neither necessary nor crucial to do so, especially if one takes into account that it is not, as it has been previously elaborated, even certain that the case does indeed represent an anthroponym. Our intention was exactly to use this famous example to present the full complexity of the problems that relate to the field of early Hellenic anthroponymy, as well as to present the difficulties that may arise from the very nature of the source.

The first unambiguous evidence of Nestor being used as a personal name come from the later periods of Ancient Greek history. However, if one looks at the distribution of this name across geographical and ethnic entities and regions in all the areas of the Hellenic world, one can unavoidably arrive at the conclusion that the emergence of this name as a personal name is not determined by ethnic and regional division within the Hellas itself. Nestor as a heroic name and as an anthroponym, on the contrary, bears all the trademarks of a name with clear and outstanding pan-Hellenic characteristics. In other words, the name Nestor, as a personal name, is almost equally common in the Ionian areas of the Hellenic World (Attica, the islands in the Cyclades, Ionia in Asia Minor), as it is in the predominantly Doric areas (Peloponnese, the islands of the Sporades), but also in Epirus, Macedonia and in the Hellenic settlements beyond the mainland Greece. It is indisputable that this distribution of the name must have been influenced by the fact that Nestor was one of the most notable heroes of ancient Hellenic epics with a significant role in the two most important Homeric epics. - the Iliad and the Odyssey. Nestor is the oldest, but also the wisest of all Achaean warriors in the siege of Troy. Although his former great strength withered in his old age, in the epic he is still the embodiment of courage and of the spirit of a great warrior who inspires the younger generations to bravely march into battle. That is why the young respect him. Yet, it is not in his role of a battle-hardened warrior that Nestor's contribution is most visible, but in his roles of a skilled and wise speaker and adviser, which are the roles that unquestionably befit his age, experience and authority. This again tells us a lot about a society in which "good advice" and "muscle power" were equally appreciated. ${ }^{18}$ Nestor's appearance and posture are primarily royal and

\footnotetext{
${ }^{17}$ Cf. Mühlestein 1987: 4-5 = Mühlestein 1965: 158-159. Also Ilievski 2000: 302.

${ }^{18}$ Which is confirmed, for example, by what Agamemnon says to Nestor, Il. II 370-374: "Aye verily once more,
} 
aristocratic, while the attributes which are used to describe him - such as hipota (for

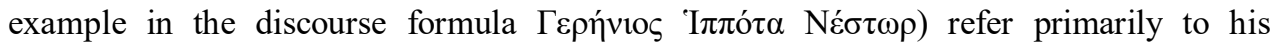
reputation as a chariot warrior, but also as a horseman in general, a knight, a breeder of finest horses, as befits a grandson of god Poseidon. ${ }^{19}$ Hence, Nestor's name may have been attractive for naming children among the nobility in those Greek poleis where a particular attention had been paid to breeding horses. Nestor is also one of the few Achaean heroes who successfully and uneventfully returned home after the final act of the Trojan drama. Moreover, after the hero's return, his home, as described in the Odyssey, leaves an impression of harmony and of healthy family relations, all of which are the attributes of happiness and of a destiny which every Hellene going through hardships could wish he or his family members possessed.

All of this, therefore, may be interpreted as a set of good reasons for the name Nestor to appear as a personal name in the Hellenic world. Someone who is the personification of a long life, but also of a happy and vigorous old age, and of wisdom, eloquence and personal courage on top of it, could not have been but a good example and role model for the next generations. Consequently, parents may have been giving this name to their newborn male children in the hope that they would live a life similar to Nestor's. The name Nestor, as a personal name, may have, however, also appeared in those families who have claimed to have been related to this great hero. In such cases, the heroic name used as an anthroponym would have directly pointed to the origin of the family. The nature of our predominantly Athens-centric narrative sources immediately brings to mind the leading Athenian families from the Archaic period, such as the Alcemonids and the Peisistratides, who used their noble Neleid heritage, be it real or made up, which is of secondary importance for the issues discussed in this paper, as capital in their political struggles. However, that it had not been these famous Athenian families who were the only ones to have claimed direct lineage to Nestor and other Neleidae from Pylos, can be proven by a well-known inscription from the island of Kos from the classical era in which there is a calendar of sacrifices and feasts of different communities from the island which also contains a reference to a tribe's lineage, or to another group of the same tribe (maybe triakas or "a thirtieth part"), ${ }^{20}$ which happened to be named exactly the Nestoridai.The

old sir, art thou pre-eminent in speech above the sons of the Achaeans. I would, O father Zeus and Athene and Apollo, that I had ten such counsellors; then would the city of king Priam forthwith bow her head, taken and laid waste beneath our hands..."(translation by A.T. Murray). Cf. also Plutarch's essay Should Old Men Take Part in Affairs of State? (An seni respublica gerenda sit) on the necessity of the elderly taking part in state and public affairs, where Nestor is mentioned as the best "historical" example for this claim (Plut. Mor. 788-790; 795). Regarding the term euboulia and its practical meaning in understanding honor and virtue in the examples from the Iliad/1\} which are important for the entire Hellenic education and upbringing, cf. a very interesting discussion: Schofield 1986: 6-31. For a somewhat revisionist position on Nestor as a "good counselor", cf. a very recent source Roisman 2005: 17-38.

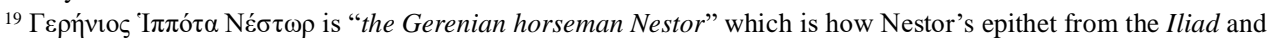
Odyssey was translated by Anthony Verity. This phrase occurs as many as 25 times in the Illiad and 11 times in the Odyssey. Cf. Hainsworth 1993: 80. For the origin of the name Гєрฑ์vios (Gerenian), see also Brillante 1996: 209-219.

${ }^{20}$ For more information on triakades (thirtieths) on Kos and their position within the tribe, cf. Jones 1987: 238239. 
calendar specifically records that on the day when a bull is being sacrificed to Zeus

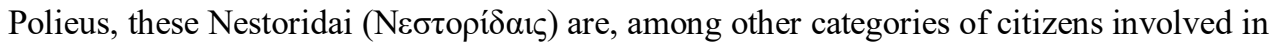
religious sacrifices, are to be provided with a portion of the sacrificial animal's flesh. ${ }^{21}$ The name of the family line, the Nestoridai, with the characteristic suffix -idai points, without any doubt, to a conclusion that the members of this group considered a Nestor as their common ancestor. The question remains if the group was named after a local, presently unknown,Nestor, which is less likely, or after the hero Nestor, the son of Neleus, which is certainly more likely. ${ }^{22}$ Mythical links of the local community with the great here was not, as it turned out, that difficult to find. Nestor's roots, as a son of Neleus and grandson of Poseidon and Type, go back to Thessaly where, in the vicinity of Iolcos, on the slopes of Pelion, the centaur Chiron raised and trained Asclepius, the patron of medical skills and of the famous medical school on the island of Kos. In addition to this, on the island which was famous for its worship of god Asclepius and his medical skills, it was not without significance that it was exactly Nestor who was, in the older of the two Homeric epics, described as a hero who, during the siege of Troy, pulled, while driving his chariots, the wounded hero and physician Machaon, a son of Asclepius and the ruler of Thessaly. ${ }^{23}$ A testimony that on the island of Kos the very name Nestor was appreciated to such an extent that it may have been given to children is the existence of the personal

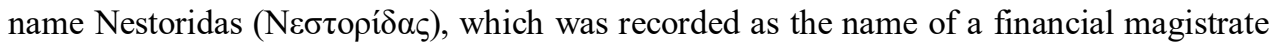
on a coin from the island of Kos, which was struck in the period of the rule of Mausolus, a dynast of Caria, and of the family Hecatomnides, immediately after the synoecism of the island some time between $366 / 5$ and 350 BC. ${ }^{24}$ This is, to my knowledge, only one of the two confirmed cases, but the one which is unique in the classical epoch, that the name Nestor, as a personal name, appears in the patronymic form with the suffix -ides/idas. The suffix may primarily indicate that the father or a grandfather of the aforementioned Nestoridas was called $\mathrm{N} \varepsilon \dot{\sigma} \omega \rho,{ }^{25}$ or that he was a descendant of a Nestor in the family

${ }^{21}$ Herzog, Heilige Gesetze 1, lines 46-55. The text of the inscription, which can be with a great certainty dated to the middle of the 4th century BC, has been repeatedly reprinted and commented in various collections: Syll. ${ }^{3}$ 1025-27; Sokolowski, LSCG 151; Rhodes-Osborne, GHI 62, pgs 298-311, and quite recently in $I G$ XII 4, 1 , 278. Cf. also $I G$ XII 4, 1, 332, line 34, where the name Nestoroidai can most certainly be complemented. The Nestoridai, as a group, also built a sacrificial altar for Zeus Hikesios in Asklepieion on the island of Kos, cf.

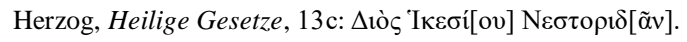

22 Which is also claimed to be a fact by Sherwin-White 1978: 165-7, who provides a whole list of groups who had derived their names from the common Hellenic traditions, or had, on the other hand, followed local myths and placed them into a bigger, Hellenic context: Alkeidai, Amphiareidai, Antimachidai, Euryanaktidai, Nebridai, Nostidai, Phyleomachidai.

${ }^{23}$ Il. XI 504-520. In a subsequent adaptation, it was also Nestor who brought to Hellas the ashes of the hero Machaon who was killed during the siege of Troy by the Amazon Penthesilea or by Eurypylus, the son of Telephus. That this story was very much current in subsequent epochs is exemplified by one of Pausanias's "periegesis" (III 26,9) which stated that Machaon's grave and tomb were located exactly in Nestor's Gerenia on the border of Messinia and Laconia, where people would come to seek cure for their illnesses.

${ }^{24}$ Cf. Sherwin-White 1978: 492; LGPN I, s.v. Nestoridas. Regarding tetradrachms of Kos with depictions of Heracles which seemed to have taken distinctive features of the Carian ruler Mausolus, cf. Sherwin-White 1978: 70-71 with note. 215; Hornblower 1982: 134.

${ }^{25}$ In Homer's epics, most certainly because of the requirements of the meter, any of Nestor's sons was called

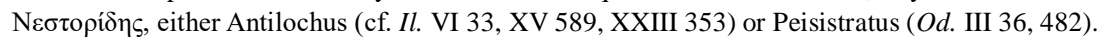


line, perhaps Nestor the hero. Subsequent patronymic word formations of the type

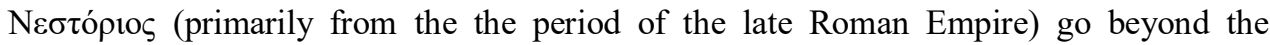
chronological and thematic scope of this paper and have therefore not been taken into

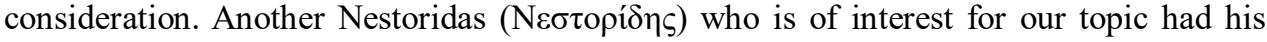
name recorded on the island of Delos in the mid-third century BC. ${ }^{26}$

As far predominantly Ionian islands in the Aegean Sea are concerned, the name Nestor as a personal name appears on the island of Amorgos, where this was the name of apparently a very respected citizen of Arkesini, who was recorded as the proponent of issuing an honorary decree for Glaucon, son of Ariston, from the island of Naxos, some time at the turn of the 4th and 3rd century BC. ${ }^{27}$ Nestor was also the name of a son of an Aelept from the island of Andors, confirmed in Delos in the period between 372 and 367 BC. ${ }^{28}$ On the other hand, as far as Doric islands are concerned, in addition to the aforementioned examples from the island of Kos, one should not be surprised that the use of the heroic name Nestor as a personal name (and the names of his sons as well) has been confirmed on Rhodes, an island and a very rich trading polis, which was the crossroads of different traditions and whose citizens, often under private auspices, maintained strong economic and political relations with members of numerous Hellenic communities in the wider Mediterranean region. The majority of confirmed occurrences of the name Nestor as a personal name among the Rhodians date back to the late Hellenistic period (from 2nd to 1st century BC). ${ }^{29}$ Again, as far as the "Doric" Peloponnese is concerned, the name Nestor as an anthroponym was confirmed in Epidaurus in Argolis as early as in the 4th century BC. ${ }^{30}$ A relationship with Asclepius, as in the case of confirmed anthroponyms from Kos, could have played a role in one of the confirmed examples.

As one would expect, important and numerous confirmed anthroponyms of the heroic name Nestor can be found in Attica. The majority of them date back to the late Hellenic period or to the Early Imperial period. ${ }^{31}$ An exception to this generalization may be an ostracon from the 5th century BC on which was recorded a part of the patronymic

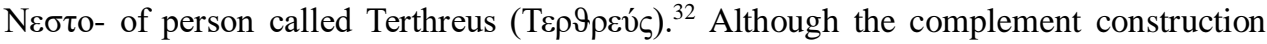

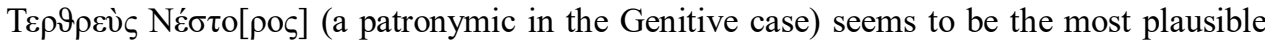
interpretation, different interpretations and readings of this inscription are also possible. ${ }^{33}$ Notwithstanding the different possible readings of the text segment, this example also

${ }^{26}$ I. Délos 290, line 124 (246 BC.). Cf. LGPN I, s.v. Nestorides.

${ }^{27} I G$ XII 7, 19. Cf. $L G P N$ I, s.v. Nestor (1).

${ }^{28}$ I. Délos 100, 8. Cf. LGPN I, s.v. Nestor (2).

${ }^{29} L G P N$ I, s.v. Nestor (5) - (7).

${ }^{30} L G P N$ III A, s.v. Nestor (1).

${ }^{31}$ Cf. $L G P N$ II, s.v. Nestor (2) - (12).

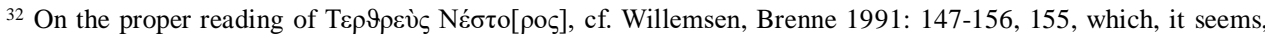
was rightly adopted by the publishers of the second volume of Oxford Lexicon of Greek Personal Names by M. J. Osborne and S.G. Byrne: $L G P N$ II, s.v. Nestor (1).

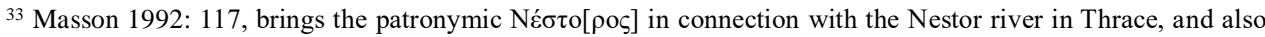
draws attention to names of this type which were popular on the island of Thasos in the classical period:

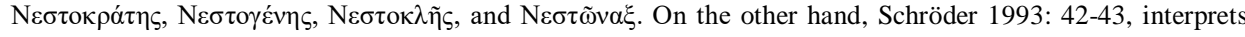

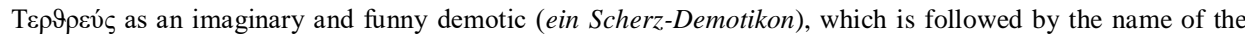
possible ostracism candidate in the Nominative case or a patronymic in the Gentive case. 
shows the extent to which ostracons represent a unique and important source for anthroponymy and prosopography of Attica in the fifth century BC, as they recorded personal names which cannot be found in other surviving sources. On the other hand, Nestor, a Hellenic settler in Egypt from the third century (dated to 247 BC), who is recorded in the Oxford Lexicon of Greek Personal Names as a possible Athenian, most probably was not an Athenian, as the entry Athenaios, which stands next to his name is more likely a patronymic than an ethnonym. ${ }^{34}$

It is also interesting that in Egypt, both in the period of the Ptolemaic dynasty and in the imperial epoch, we only rarely find conformations of Nestor as a personal name. ${ }^{35}$ However, one conformation of Nestor as a personal name in Egypt should be particularly emphasized. It is the famous inscription, a dedication to Ptolemy VII Euergetes II, the king of Egypt, to Queen Cleopatra the "Sister," Queen Cleopatra the "Woman" and to

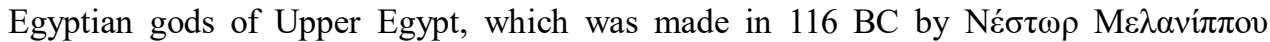
$\Phi \alpha \sigma \eta \lambda i$ in (born, obviously, in the Greek polis of Phaselis in Pamphylia in Asia Minor). $\mathrm{He}$ was a high-ranking person in the royal administration (among $\tau \tilde{\omega} \mathrm{v}$ $\dot{\alpha} \rho \chi 1 \sigma \omega \mu \alpha \tau \sigma \varphi v \lambda \alpha \dot{\alpha} \omega v)$, and at the time when the dedication was made he was the commander of the king's military garrison in Siena and Elephantine in Upper Egypt. ${ }^{36}$ In

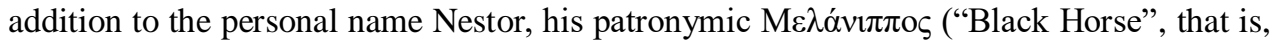
metaphorically speaking, "the one who breeds black horses") also draws one's attention, as this also more than a good heroic name (out of several people named Melanippus from different epics and myths, the first one who springs to mind is probably Melanippus, the son of Astacus, the defender of Thebes in Seven Against Thebes). A combination of heroic names from various mythical and epic cycles and their occurrences as personal names within a single family represent one of the trademarks of the Late Hellenistic period. These occurrences were definitely no longer a matter of giving names so as to emphasize or imply the family line of the holder of the name: instead, the reasons for the emergence of these anthroponyms should be sought in the general popularity of myths, as well as in the predominant cultural climate and the general taste of the epoch. The heroic names which occurred in these father-son combinations were, as a general rule, the names of the great heroes taken from the most important cycles - the Trojan one and the Theban one.

On the other hand, the name Nestor as a personal name was also popular in Epirus, where, during the Hellenistic period, there was by far the biggest number of its confirmed occurrences, mostly in the epigraphic materials from Buthrotum from the second century BC. ${ }^{37}$ Buthrotum, an important port and city in Epirus opposite the island of Corfu, founded, according to the legends, Helenus, a son of the king Priam of Troy, but one should not easily discard the possibility that the very hero Nestor, or one of his descendants, played a role in the mythical history of the city and of Epirus in general. ${ }^{38}$

${ }^{34} L G P N$ II, s.v. Nestor (10). In P.Hib. 130 it is written NÉ $\tau \omega \rho \rho$ A $9 \eta v \alpha[i ́ o v]$ and this is most certainly an instance

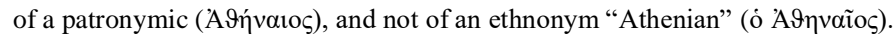

${ }^{35}$ Cf. Preisigke-Littmann, Namenbuch, s.v. Nestor; Foraboschi, Onomasticon, s.v. Nestor.

${ }^{36}$ SEG 28, 1484; Bernard, De Thèbes à Syène 320. Cf. LGPN V B, s.v. Nestor (19).

${ }^{37} L G P N$ III A, s.v. Nestor (3) - (16).

38 For a general overview of the complexity of heroic genealogies and of the mythical geography and colonization of Epirus within the framework of Odysseus's, but not only of Odysseus's, Nostoi, cf. Malkin 
And among Epirean Nestors, some of which were also recorded in narrative sources, the one which is particularly worth mentioning is an Epirian who is mentioned in one of Polyaenus's stratagems, from his collection of examples of military stratagems (Strategemata), where it is stated that he was one of "Alexander's bodyguards" ( $\tau \tilde{\mathrm{\omega}} \mathrm{v}$ A $\lambda \varepsilon \xi \alpha \dot{\alpha} \delta \delta \rho 0 v \sigma \omega \mu \alpha \tau о \varphi v \lambda \alpha \dot{\alpha} \omega \nu) .{ }^{39}$ This Nestor, of course, could not have been a member of the personal guard of Alexander the Great, but, almost certainly, of the one of the Epirean ruler Alexander II, of the Aeacid dynasty. Some time around the year 235 BC, the king's bodyguard Nestor was bribed to kill Deidameia, an Epirean princess and a daughter of the famous king Pyrrhus. However, fascinated by her beauty and noble posture, he was not able to finish the work for which he had been hired. ${ }^{40}$ It is unfortunate that we know nothing more about this Nestor, while Polyaenus did not even mention his patronymic. However, regardless of this, the position of somaphothilak, which in antiquity and in the traditions of Maceodnian and Epirean rulers meant much more than is implied by term "bodyguard" which is nowadays mostly used to translate it, points to a conclusion that this Nestor belonged to the circle of Epirean aristocracy, i.e. to a family which was closely related to the royal family. It was probably exactly out of respect for the Aeacid royal family that he could not have assassinated the princess, hence another assassin was found who did not hesitated to kill Deidameia inside the temple of Artemis. The second historically interesting Nestor was reliably mentioned by Polybius, a historian, as a friend of the Roman consul Aulus Hostilius in 170 BC (he, therefore, must have been born around the end of the 3rd century $\mathrm{BC}$ and, just like the previously mentioned Nestor, he must have been a member of the local aristocracy), adding as an additional piece of information, as a better determinant of his origin, an ethnonym or a nickname ó K $\rho \omega ́ \pi t o s$, which cannot be easily explained. ${ }^{41}$ On his way to join the army which was stationed in Thessaly, consul Hostilius extended his stay at Nestor's residence in Epirus, in a place called Phanota, which gave his enemies an opportunity to try to organize his capture. Nestor composure and determination, however, made it possible for the consul to successfully evade the trap that had been prepared for him. Both the first and the second example seem to confirm that the anthroponym Nestor was in Epirus rightly given to people who, in accordance with the meaning of their name in the Hellenic tradition and with the saying nomen est omen, had proven to be good advisers and confidants.

It is through Epirean influence that one could explain occurrences of the name Nestor, during the Hellenistic era, in Illyria in the ancient Greek settlement of EpidamnDirah or in the nearby Dimale. ${ }^{42}$ Likewise, occurrences of the heroic name Nestor as a

1998: 120-155. It is certainly not without importance for the genealogical mindset and comprehension of history that Nestor's daughter Polycaste was married to Odysseus's son Telemachus.

${ }^{39}$ Polyaen. VIII 52.

${ }^{40}$ Cf. F. Geyer, RE 17, 1936, 123-124, s.v. Nestor (2) = LGPN III A, s.v. Nestor (3).

${ }^{41}$ Polyb. XXVII 16, 4-6; F. Geyer, RE 17, 1936, 124, s.v. Nestor (3). Cf. LGPN III A, s.v. Nestor (16). The

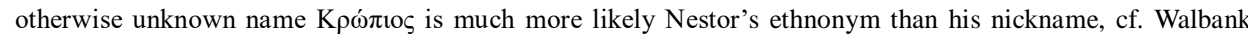
1979: 317 ad Polyb. XXVII 16. Cabanes 1976: 327 note 427, claim, on the other hand, that there is a

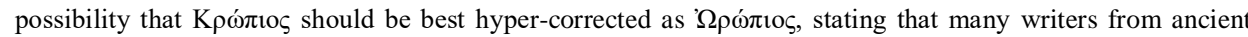
times note that there existed a town with this name in Epirean Thesprotia : St. Byz. s.v. ' $\Omega \omega \pi$ ós.

${ }^{42} L G P N$ III A, s.v. Nestor (17) - (19). It cannot be neglected as unimportant that one of the magistrates of the city of Epidamn, on the coins struck during the Hellenistic period between the years 250 and 50 BC, was 
personal name have also been confirmed in Macedonia, ${ }^{43}$ where the names which had been taken from myths and epics were particularly appreciated and were often and willingly given to children. Among the "Macedonian" Nestors, our attention is mostly attracted by an inscription containing the patronymic Nestor of a citizen from Edessa in Macedonia, only the ending of whose name has survived [---] $\alpha \sigma \tau$ o (maybe ['A $\delta \rho] \alpha \sigma \tau o \varsigma$ ?, which is also a fine heroic name), and who, together with several of his fellow citizens, had been awarded honors (proxenia, euergesia) in Haliartus in Beotia. ${ }^{44}$ It is not entirely certain if the inscription from Haliartus should be dated to the early Hellenistic epoch at the turn of the 4th and 3rd century BC, or it should be dated somewhat more recently to the beginning of the 2 nd century BC. ${ }^{45}$ On the other hand, a Nestor (N $\left.\varepsilon \sigma \sigma \tau \omega \rho\right)$, the father of Deinon, who was appointed proxenus in Thermon by the Aetolians toward the end of the 3rd century (around the year 200 BC), was probably from Europe in Epirus and not from the town with the same name in Macedonia. ${ }^{46}$

The name Nestor, as an anthroponym, is also very frequent in Asia Minor and the majority of confirmed occurrences date back to the period of the Roman Empire. As far as ancient Greek poleis in Ionia in Asia Minor are concerned, towards the end the Hellenistic era, occurrences of the heroic name Nestor were recorded in Priene where, apparently, it had been passed on from one generation to another, ${ }^{47}$ and, in regard of the neighboring poleis, the name was also confirmed in the region of the Gulf of Latmia, and in Heraclea by Latmus, where a dedicant had this name, who, together with the members of his thiasos-, made a very significant dedication to the Egyptian gods Sarpis, Isis and Anubis. ${ }^{48}$ As it can be expected, given the Neleid history of the polis and its tradition, the name Nestor, as an anthroponym, was also used in the nearby Miletus, i.e. in the famous Temple of Apollo in Didyma, in the late Hellenistic period, that is in the Early Imperial periods, ${ }^{49}$ while its occurrence in Ephesusa can only be confirmed during the Imperial period, both among citizens and among newcomers. ${ }^{50}$ On the other hand, the hero Nestor, as it seems,

named exactly Nestor. Cf. also Münsterberg 1985: 40.

${ }^{43} L G P N$ IV, s.v. Nestor (1) - (4).

${ }^{44} I G$ VII 2848.

${ }^{45}$ Cf. Tataki 1998: 103-104; LGPN IV, s.v. Nestor (1).

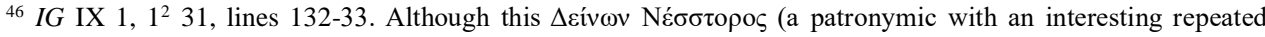
Sigma) Eủpót $\pi$ ○̧ is in the group of people from various Epirean town in the Thermon region, Op. cit., 108, classifies him as a Macedonian from Europe; on the other hand, P. Fraser and E. Matthews, publishers of the Oxford Lexicon of Greek Personal Names, rightly adapt the view that the awarded person was from Europe in Epirus: LGPN III A, s.v. Nestor (15). Cf. also Cabanes 1976: 364-5 with the note. 75.

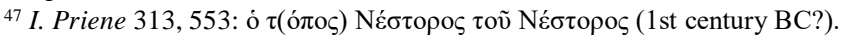

${ }^{48}$ The inscription is difficult to date reliably, but it was probably made during the Imperial era. Cf. RICIS 304; $L G P N$ V B, s.v. Nestor (2).

${ }^{49}$ The father of one of the treasurers of the temple in Didim in the first century BC was most certainly called

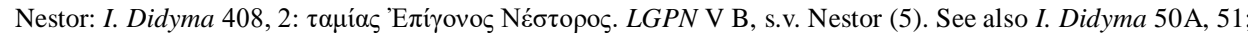
Milet I 3, 161, line 3; Milet I 9, 385 (SEG 4, 425). Cf. LGPN V B, s.v. Nestor (3)-(7).

${ }^{50}$ For example, I. Eph. 1239, a dedication to Zeus Ceraunean which had been made by the priest $\Delta \eta \mu \eta \dot{\tau} \tau$ io

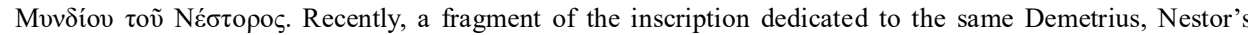
grandson, was published, cf. Büyükkolanci, Engelmann 1998: 74-75, and the publishers dated both inscriptions to the first half of the 1st century BC. Cf. also I. Eph. 3067, an honorary inscription for the poet Nestor, no doubt made by Lucius Septimus Nestor of Laranda in Lycaonia, who is well-known from a whole 
was, at least during the period of the Roman Empire, considered the mythical founder of Sinope in Pontus. ${ }^{51}$ The city of Sinope was, most certainly, an old Milesian colony, which had been, according to legends, founded on several different occasions. ${ }^{52}$ Over time, in the city's rich history, a place was found also for the hero Nestor. It was probably the desire of Sinope's citizens to establish a connection between their city and a nostoi hero, and Nestor, the son of Neleus, was particularly suitable for this purpose. A similar case was also recorded in southern Italy, where Nestor was considered to have been the founder of the colony Metapontum. In case of establishing this well-known Hellenic settlement in southern Italy, it was probably again a matter of citizens wishing not to fall behind other Hellenes in this respect, so they wanted to find for themselves a founder from the heroic epoch who was worth mentioning. That is how instead, or, to be more precise, simultaneously with, the historical Achaeans from the north of the Peloponnese, who really did found Metapontum some time in the 7th century BC via their main settlement Sybaris, the whole founding story was expanded with heroic, epic Achaeans - Nestor and his warriors of Pylos. ${ }^{53}$ It is exactly for these reasons that one should not expect for the name Nestor to have appeared in Sinope or Metapontum, and maybe in some other Greek settlements, where Nestor the hero may have been worshiped as a real or mythical founder of these cities.

Among Nestors from Asia Minor, however, one should definitely single out a Nestor who is mentioned as a magistrate on the coins from Kimah during the Hellenistic period. ${ }^{54}$ In the interior of Caria, in Pisidia-Pladasa, there were several interesting recorded occurrences of the name Nestor as a personal name in the 3rd century BC. ${ }^{55}$ Again, some other confirmed occurrences of the name Nestor as an antroponym are, in their own way, interesting. Thus, a certain citizen of Tralee from Asia Minor, who is mentioned in an inscription found on the island of Kos, was called Nestor, while his father had also had a

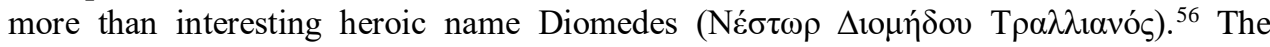
father-son combinations of this kind which contain names of great heroes can tell us a lot about the people who had the names of this kind, about their views, their aspirations, about the taste of an entire epoch, as it has already been shown with similar documented

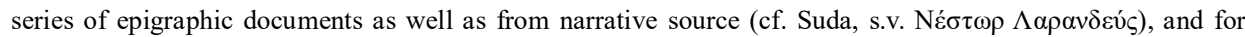
father Peisander, also an epic poet, during the reign of Alexander Severus.

${ }^{51}$ This is the indication which can be made on the basis of a recently published epigram from the tombstone from

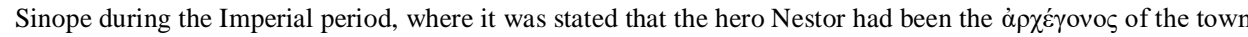
(I. Sinope 173, lines 3-4). Cf. SEG 51, 2001, 1730

52 Cf. eg. Ps. Skymnos, 981-997, for the overview of the complexity of legends that had been told about the founding of Sinope.

${ }^{53}$ Strab. VI 1, 15, states that Metapontum was originally founded by Nestor and "Pylosenas" on their way back from Troy, and that the town was later destroyed by the Samnites. Metapontum was, according to popular belief (Eus. Chron. Arm.), founded as early as in 733/2 BC, but the oldest archeological traces data only to the 7th century. Cf. Malkin 1998: 211-212, for the cult of the Neleid in Metapontum and for the possible reasons why the search for a "suitable" founder of the town should start from exactly Nestor.

${ }^{54}$ Masson 1990: 530. Cf. R. Münsterberg 1985: 76.

${ }^{55}$ Cf. $L G P N$ V B, s.v. Nestor (8)-(9).

${ }^{56}$ Herzog, Koische Forschungen 105. Cf. LGPN V B, s.v. Nestor (10). 


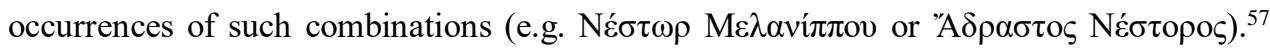
Likewise, it is not surprising, given the reputation of a wise counselor and a good orator which the hero Nestor enjoyed especially among educated Hellenes, that it is approximately towards the end of the Hellenistic epoch and round the beginning of the Imperial period that there were documented occurrences of the name Nestor as a personal name among the members of local elites both in Hellenic and in Hellenized areas. For instance, geographer Strabo, among many prominent people worth mentioning in Tarsus in Cilicia, mentioned two Nestors who were philosophers: a Stoic and a Platonist. ${ }^{58}$ If we add to this perhaps the best known Nestor from the period of the Roman Empire, the epic poet Nestor of Laranda, ${ }^{59}$ it seems that the name Nestor may have sounded to the contemporaries as a good name for a wise and educated Hellene. ${ }^{60}$ In this way, the reasons for giving the name Nestor to newborn Hellenic children gradually, as had been the case with some other heroic names but also with some which were not associated with heroes, moved from the sphere of politics to the sphere of culture: from possible mythical links and claiming one's lineage originating from the hero, which are exemplified by formations

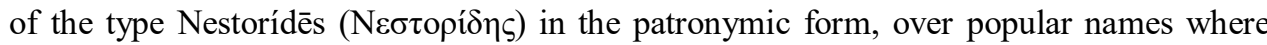
the anthroponym Nestor appears in a combination with other heroic names, the process reached a point when educated members of local elites in Greek cities of the Hellenistic and of the Roman epoch, because they perceived Nestor as a model of a wise and educated man, teacher and counselor, found it totally acceptable to name their children Nestor. On the other hand, in Rome itself the anthroponym Nestor, just like many other Greek heroic names, most frequently occurred as the name of slaves and freedmen. ${ }^{61}$

\footnotetext{
${ }^{57}$ In some places this combination has also been attested with pseudo-historical, as well as with historical, names, such as in Carallia in Cilicia where an inscription from the 1 st century BC mentioned that a father had

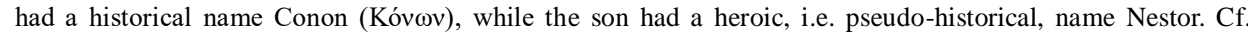
$L G P N$ V B, s.v. Nestor (16).

${ }^{58}$ Strab. XIV 5, 14. Nestor the Stoic from Tarsus in Cilicia could have been Panaetius's student (2nd-1 st century BC), cf. A. Modrze, $R E$ 17, 1936, 124, s.v. Nestor (5) = LGPN V B, s.v. Nestor (12), while Nestor the Academician was best known as a teacher of Marcellus, nephew of Augustus, although, as Strabo informs us, he had at one point administered the city of Tars. Cf. A. Modrze, $R E$ 17, 1936, 124, s.v. Nestor (4).

${ }^{59}$ On Septimus Nestor of Laranda, cf. $O C D^{3}$ s.v. Nestor (2). His son, who was also a poet, had a good Greek heroic namе грчко херојско име Peisander (see above, note 50).

${ }^{60}$ One should therefore not be surprised that the name Nestor, as a part of the Hellenic heritage, had been passed on to Christians and that, consequently, several prominent bishops and religious martyrs from towns in Asia Minor had that name in the period of late antiquity (3rd-5th century AD). Cf. W. Enßlin, $R E 17,1936,124$, s.v. Nestor (6)-(8).

${ }^{61}$ Cf. Solin 1982: 503-504, who mentions a total of 28 attested occurrences of the name Nestor: "only" two (2) freeborn men, thirteen (13) slaves and freedmen and thirteen (13) people bearing this name whose origin was either unknown or difficult to determine for certain. Cf. also Solin 1982: 1365, for the name Nestor when it occurs as a cognomen.
} 


\section{REFERENCES:}

List of abbreviations of epigraphic and lexicographical publications:

Arena, Iscrizioni III = R. Arena, Iscrizioni greche arcaiche di Sicilia e Magna Grecia. Iscrizioni di Sicilia, III. Iscrizioni delle colonie Euboiche, Pisa 1994.

Bernard, De Thèbes à Syène = A. Bernand, De Thèbes à Syène, Paris 1989.

Chantraine, $D E L G=\mathrm{P}$. Chantraine, Dictionnaire étymologique de la langue Grecque. Histoire des mots, I-IV, Paris 1968-1980.

DNP = Der neue Pauly: Enzyklopädie der Antike, hrsg. H. Cancik, H. Schneider, Stuttgart, Weimar 1996-2003.

Dubois, IGDGG = L. Dubois, Inscriptions Grecques Dialectales de Grand Grèce. I, Colonies eubéennes. Colonies ioniennes. Emporia, Geneve 1995.

Foraboschi, Onomasticon = D. Foraboschi, Onomasticon Alterum Papyrologicum, Milano 1967.

Frisk, GEW = H. Frisk, Griechisches etymologisches Wörterbuch, I-III, Heidelberg 1954-1973.

Herzog, HGK = R. Herzog, Heilige Gesetze von Kos, Berlin 1928.

Herzog, Koische Forschungen = R. Herzog, Koische Forschungen und Funde, Leipzig 1899.

I. Délos = Inscriptions de Délos I-VII (edd. F. Durrbach, P. Roussel, M. Launey), Paris 1926-1972.

I. Didyma = A. Rehm, Didyma, II. Die Inschriften, hrsg. von R. Harder, Berlin 1958.

I. Eph. = H. Wankel, R. Merkelbach et alii, Die Inschriften von Ephesos, I-VII (Inschriften griechischer Städte aus Kleinasien Band 11-17), Bonn 1979-1981.

$I G=$ Inscriptiones Graecae:

IG VII = Inscriptiones Graecae VII. Inscriptiones Megaridis, Oropiae, Boeotiae, ed. W. Dittenberger, Berlin 1892.

IG IX 1, $1^{2}=$ Inscriptiones Graecae IX,1. Inscriptiones Phocidis, Locridis, Aetoliae, Acarnaniae, insularum maris Ionii, ed. G. Klaffenbach, Berlin 1932-1968.

IG XII 4 = Inscriptiones Graecae XII,4. Inscriptiones Coi, Calymnae, insularum Milesiarum, ed. K. Hallof, Berlin 2010-2012.

IG XII 7 = Inscriptiones Graecae XII,7. Inscriptiones Amorgi et insularum vicinarum, ed. J. Delamarre, Berlin 1908.

I. Priene = F. Hiller von Gaertringen, Inschriften von Priene, Berlin 1906 .

I. Sinope = D. H. French, The Inscriptions of Sinope. Part I (Inschriften griechischer Städte aus Kleinasien, Band 64), Bonn 2004.

Jeffery, $L S A G=$ L. H. Jefery, The Local Scripts of Archaic Greece, Oxford 1961.

$L G P N=A$ Lexicon of Greek Personal Names:

$L G P N$ I = P. M. Fraser, E. Matthews (edd.), A Lexicon of Greek Personal Names I: The Aegean Islands, Cyprus and Cyrenaica, Oxford 1987.

LGPN II = M. G. Osborne, S. G. Burne (edd.), A Lexicon of Greek Personal Names II: Attica, Oxford 1994.

LGPN III A = P. M. Fraser, E. Matthews (edd.), A Lexicon of Greek Personal Names IIIA: The Peloponnese, Western Greece, Sicily and Magna Graecia, Oxford 1997.

$L G P N$ III B = P. M. Fraser, E. Matthews (edd.), A Lexicon of Greek Personal Names IIIB: Central Greece: From the Megarid to Thessaly, Oxford 2000.

$L G P N$ IV = P. M. Fraser, E. Matthews (edd.), A Lexicon of Greek Personal Names IV: Macedonia, Thrace, Northern Regions of the Black Sea, Oxford 2005.

LGPN V A = Th. Corsten, R.W.V. Catling, M. Ricl (edd.), A Lexicon of Greek Personal Names V A: Coastal Asia Minor: Pontos to Ionia, Oxford 2010.

$L G P N$ V B = J.-S. Balzat, R.W.V. Catling, E. Chiricat, F. Marchand, Th. Corsten (edd.), A Lexicon of Greek Personal Names V B: Coastal Asia Minor: Caria to Cilicia, Oxford 2013. 
LIMC VII = Lexicon Iconographicum Mythologiae Classicae, Band VII, Zürich - München 1994.

Milet $=$ Milet . Ergebnisse der Ausgrabungen und Untersuchungen seit dem Jahre 1899 (edd. Th.

Wiegand et al.), Berlin 1906-2006:

Milet I 3 = G. Kawerau, A. Rehm, Das Delphinion in Milet, Berlin 1914.

Milet I 9 = A. von Gerkan, F. Krischen, Thermen und Palaestren, Berlin 1928.

Meiggs - Lewis, GHI = R. Meiggs, D. Lewis, A Selection of Greek Historical Inscriptions, Oxford 1969.

$O C D^{3}=$ S. Hornblower, A. Spawforth (edd.), The Oxford Classical Dictionary, Oxford $1996^{3}$.

P.Hib. = The Hibeh Papyri I, ed. B. P. Grenfell and A. S. Hunt, London 1906.

Pape - Benseler = W. Pape, G. E. Benseler, Handwörterbuch der griechischen Sprache. Bd. 3: Wörterbuch der griechischen Eigennamen, Braunschweig 1863-1870.

Preisigke-Littmann, Namenbuch = F. Preisigke, E. Littmann, Namenbuch, Heidelberg 1922.

$R E=$ Pauly-Wissowa (edd.), Real-Encyclopädie der classischen Altertumswissenschaft, Stuttgart 1893-1980.

RICIS = L. Bricault, Recueil des inscriptions concernant les cultes isiaques, I-III, Paris 2005.

Rhodes-Osborne, GHI = P. J. Rhodes, R. Osborne (edd.), Greek Historical Inscriptions 404-323 BC, Oxford 2003.

SEG $=$ Supplementum Epigraphicum Graecum, Leiden-Amsterdam 1923- .

Sokolowski, $L S C G=$ Lois sacrées des cités grecques, ed. F. Sokolowski, Paris 1969.

Syll. ${ }^{3}$ = W. Dittenberger (ed.), Sylloge Inscriptionum Graecarum ${ }^{3}$. Vol. I - III, Leipzig 1915 - 1920.

References:

Andersen, O. and Haug, D. T. T. Relative Chronology in Early Greek Poetry, Cambridge: Cambridge University Press, 2012.

Bechtel, F. Die historischen Personennamen des Griechischen bis zur Keiserzeit, Halle a. d. S.: Max Niemeyer, 1917.

Brillante, C. 'Nestore Gerenio: le origini di un epiteto', in: E. De Miro, L. Godart, A. Sacconi (eds.), Atti e memorie del secondo congresso internazionale di micenologia 1991, Roma: Gruppo Editoriale Internazionale, 1996, 209-219.

Büyükkolanci, M. and Engelmann, H. 'Inschriften aus Ephesos', Zeitschrift für Papyrologie und Epigraphik, 120, 1998, 65-82.

Cabanes, P. L'Épire de la mort de Pyrrhos à la conquête romaine (272-167 av. J.C.), Paris: Belle Lettres, 1976.

Faraone, C. A. 'Taking the "Nestor's Cup Inscription" Seriously: Erotic Magic and Conditional Curses in the Earliest Inscribed Hexameters', Classical Antiquity, 15, 1996, 77-112.

Frame, D. The Myth of Return in Early Greek Epic, New Haven: Yale University Press, 1978.

Gantz, T. Early Greek Myth. A Guide to Literary and Artistic Sources, Baltimore, London: The Johns Hoplins University Press, 1993.

Hainsworth, B. The Iliad. A Commentary, Vol. III, Books 9-12, Cambridge: Cambridge University Press, 1993.

Hansen, P. A. 'Pithecusan Humour. The Interpretation of 'Nestor's Cup' Reconsidered', Glotta, 54, 1976, 25-43.

Heubeck, A. 'Bemerkungen zu einigen griechischen Personennamen auf den Linear-B Tafeln', Beiträge zur Namenforschung, 8, 1957, 28-35.

Hornblower, S. Mausolus, Oxford: Clarendon Press, 1982.

Ilievski, P. Hr. The Life of Mycenaeans in Their Own Records: With a Special Regard to the Onomastic and Prosopographic Deductions, Skopje: Makedonska akademija na naukite i umetnostite, 2000. [Илиевски, П. Хр., Животот на Микенците во нивните писмени 
сведочтва: со посебан осврт кон ономастичките и просопографски изводи, Скопје: Македонска академија на науките и уметностите, 2000]

Janko, R. Homer, Hesiod and the Hymns: Diachronic Development in Epic Diction, Cambridge: Cambridge University Press, 1982.

Jones, N. F. Public Organization in Ancient Greece: A Documentary Study, Philadelphia: American Philosophical Society, 1987.

Kamptz, H. von. Homerische Personennamen: sprachwissenschaftliche und historische Klassifikation, Göttingen: Vandenhoeck \& Ruprecht, 1982.

Kretchmer, 'P. Mythische Namen', Glotta, 4, 1913, 305-309.

Malkin, I. The Returns of Odysseus. Colonization and Ethnicity, Berkeley and Los Angeles: University of California Press, 1998.

Masson, O. Onomastica Graeca Selecta I-II, Pariz: Centre National de la Recherche Scientifique, 1990.

'Nouvelles notes d'anthroponymie grecque', Zeitschrift für Papyrologie und Epigraphik, 91, 1992, 107-120.

Mühlestein, H., 'Namen von Neleiden auf den Pylostäfelchen', Museum Helveticum, 22, 1965, 158159.

Mühlestein, H. Homerische Namenstudien, Frankfurt am Main: Althenäum, 1987.

Münsterberg, R. Die Beamtennamen auf den griechischen Münzen, Hildesheim, Zürich, New York: Georg Olms, 1985.

Murray, O. 'Nestor's Cup and the Origins of the Greek Symposion', in: B. d'Agostino, D. Ridgway (eds.), APOIKIA. Scritti in onore di G. Buchner, Naples: Instituto universitario orientale, 1994, 47-54.

Obradović, M. 'Herojsko ime Antiloh kao lično ime kod Helena', Istraživanja, 23, 2012, 95-109. [Обрадовић, М. „Херојско име Антилох као лично име код Хелена“, Истраживања, 23, 2012, 95-109.]

. 'Prilozi proučavanju neleidske antroponimije II: herojsko ime Trasimed kao lično ime kod Helena', Istraživanja, 24, 2013, 23-39. [Обрадовић, М. „Прилози проучавању нелеидске антропонимије II: херојско име Трасимед као лично име код Хелена“, Истражсиаға, 24, 2013, 23-39.]

. 'Prilozi proučavanju neleidske antroponimije III: herojsko ime Pejsistrat kao lično ime kod Helena’, Istraživanja, 25, 2014, 25-42. [Обрадовић, М. „Прилози проучавању нелеидске антропонимије III: херојско име Пејсистрат као лично име код Хелена“, Истраживања, $25,2014,25-42$.

Pavese, C. O. 'La iscrizione sulla kotyle di Nestor da Pithekoussai', Zeitschrift für Papyrologie und Epigraphik, 114, 1996, 1-23.

Powell, B. B. Homer and the Origin of the Greek Alphabet, Cambridge: Cambridge University Press, 1991.

Roisman, H. 'Nestor the Good Counsellor', Classical Quarterly, 55, 2005, 17-38.

Rüter, K. and Matthiessen, K. 'Zum Nestorbecher von Pithekussai', Zeitschrift für Papyrologie und Epigraphik, 2, 1968, 231-255.

Schofield, M. 'Euboulia in the Iliad', Classical Quarterly 36, 1986, 6-31.

Schröder, S. 'Nochmals zum Ostrakon gegen Krates Athmoneus', Zeitschrift für Papyrologie und Epigraphik, 96, 1993, 37-45.

Sherwin-White, S. M. Ancient Cos: An Historical Study from the Dorian Settlement to the Imperial Period (Hypomnemata 51), Göttingen: Vandenhock and Ruprecht, 1978.

Solin, H. Die griechischen Personennamen in Rom. Ein Namenbuch, I-III, Berlin, New York: de Gruyter, 1982. 
Tataki, A. Macedonians Abroad: A Contribution to the Prosopography of Ancient Macedonia (Melethmata 26), Athens: Research Centre for Greek and Roman Antiquity, 1998.

Ventris, M. and Chadwick, J. Documents in Mycenaean Greek. Three hundred selected tablets from Knossos, Pylos and Mycenae with commentary and vocabulary, Cambridge: Cambridge University Press, $1973^{2}$.

Visser, E. Homers Katalog der Schiffe, Stuttgart: B. G. Teubner, 1997.

Wade-Gery, H. T. The Poet of the Iliad, Cambridge: Cambridge University Press, 1952.

Walbank, F. W. A Historical Commentary on Polybius, Vol. III: Commentary on books XIX-XL, Oxford: The Clarendon Press, 1979.

Watkins, C. 'Observations on the 'Nestor's Cup' Inscription', Harvard Studies in Classical Philology, 80, 1976, 25-40.

West, St. 'Nestor's Bewitching Cup', Zeitschrift für Papyrologie und Epigraphik, 101, 1994, 9-15.

Willemsen, F. and Brenne, S. 'Verzeichnis der Kerameikos-Ostraka', Athenische Abteilung, 106, 1991, 147-156.

\section{МИРКО ОБРАДОВИТ}

Универзитет у Београду, Филозофски факултет

\section{ПРИЛОЗИ ПРОУЧАВАҢУ НЕЛЕИДСКЕ АНТРОПОНИМИЈЕ IV: ХЕРОЈСКО ИМЕ НЕСТОР КАО ЛИЧНО ИМЕ КОД ХЕЛЕНА}

\section{Резиме}

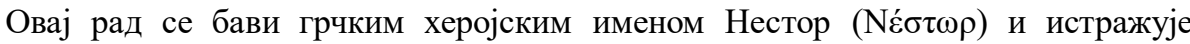
његову дистрибуцију као личног имена у старогрчком свету, од архајског до римског царског периода. Анализира се главни разлог за одабир овог херојског имена за смртнике почевши од најранијег забележеног случаја, натписа на славном скифосу из VIII века из Питекуса познатом као „Несторов пехар“ чији је власник могао бити Нестор. Име Нестор, или једна од његових верзија (Нестијанор) је већ пронађено на плочама са Линеарним Б писмом из Пила и Тебе, повремено се јавља и у различитим подручјима старогрчког света у древном периоду. Оно припада посебној категорији митолошких и херојских имена која су постала нарочито популарна међу савеменим Грцима из различитих области. Разлози за појаву имена Нестор као личног имена у грчком свету могу да буду бројни. Како митолошка традиција представља Нестора као некога ко је оличење дугог живота, срећног и здравог старог доба, али и мудрости, речитости и личне храбрости, он би такође могао да да̂ добар пример за будуће генерације. Стога је, попут других имена из херојског репортоара, и ово име постало пожељно у избору имена која су се давала деци, уз очекивање да ће носилац имена проживети свој живот као што је Нестор проживео свој.

Међутим, херојско име Нестор јавља се као лично име и у оним породицама које су тврдиле да су потекле од великог хероја. Слично томе, лично име

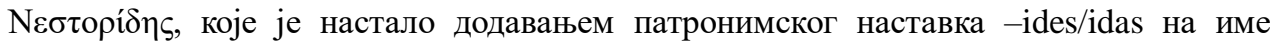
Нестор можда је било повезано са наводним пореклом genos-а или породице. Као и 
у слчају неких других нелеидских имена, херојско име Нестор је могло да делује привлачно и пожељно у именовању деце са посебним освртом на Несторово славно потомство. С друге стране, имена митолошке инспирације била су веома популарна међу образовним члановима локалне елите у хеленистичком и римском царском периоду. Херој Нестор је био парадигма мудрог учитеља и саветника. Изгледа да је у то време име Нестор можда савременицима звучало као добро име за мудрог и образованог Грка. У том смилу разлози за давање имена Нестор новорођеној деци, као и у случају неких других херојских и не само херојских имена, постепено се међу Грцима померало из домена политике у сферу културе. Лично име Нестор је потврђено у комбинацији са другим херојским именима, а ни комбинације имена

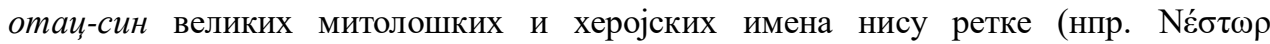

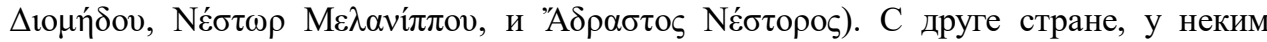
деловима Римског царства антропоним Нестор се, као и многа друга херојска имена, најчешће јавља као име за робове и ослобођене људе. Такође, у складу са римском праксом именовања, ово име се често бележило и као cognomen.

Кључне речи: Нестор, грчка антропонимија, мит, грчка епика, историја, политика, културне вредности. 